\title{
Foliar and petiole anatomy of Pterygota (Sterculioideae; Malvaceae) species and their distribution in Nigeria
}

Emmanuel Chukwudi Chukwuma, Luke Temitope Soyewo, Tolulope Fisayo Okanlawon \& Omokafe Alaba Ugbogu Forest Herbarium Ibadan (FHI), Forestry Research Institute of Nigeria, Jericho Hill, Ibadan, Oyo State, Nigeria.

Correspondence

EC. Chukwuma

E-mail: chukwuma.ec@frin.gov.ng

Received: 18 February 2017

Accepted: 26 April 2017

Published on-line: 22 June 2017

\section{Resumen}

Anatomía foliar y del peciolo de especies de Pterigota (Sterculioideae; Malvaceae)

Se estudió la anatomía foliar y del peciolo de especies de Pterygota de Nigeria, proveyendo información sobre su distribución en el área. Principalmente están distribuidas por el sur de Nigeria, especialmente en zonas más húmedas. Los microcaracteres foliares muestran que las especies son hiposteomátcas y generalmente paracíticas, más abundantes en $P$. berquaertii, con un promedio de $115 / \mathrm{mm}^{2}$, que en $P$. macrocarpa, con $59 / \mathrm{mm}^{2}$. Las células epidérmicas son irregulares, rectangulares y poligonales. El peciolo esférico con epidermis uniseriada; la distribución celular varia desde solitarias a radiales múltiples. Este estudio ha proporcionado importante información sobre las especies indígenas. Son necesarios estudios posteriores para comprender grado y tiempo de evolución independiente de las especies en Nigeria.

Palabras clave: Pterygota, Taxonomía, Foliar, Peciolo, Micromorfología, Conservación.

\begin{abstract}
Leaf and petiole anatomy of Pterygota species in Nigeria were studied and their distribution within the area is also reported, following outlined standard protocols. They are chiefly distributed in Southern Nigeria especially in wetter areas. Foliar micro-characters showed that the species are hypostomatic and generally paracytic, more abundant in $P$. berquaertii, with an average of $115 / \mathrm{mm}^{2}$, than in P. macrocarpa, where it is $59 / \mathrm{mm}^{2}$. Epidermal cells are irregular, rectangular and polygonal. Petiole spherical with uniseriate epidermis; cell distribution ranging from solitary to radial multiples. This study has provided valuable information about these indigenous species. Further systematic studies are vital to understand the number and timing of independent evolution of the species into $\mathrm{Ni}$ geria.
\end{abstract}

Key words: Pterygota, Taxonomy, Foliar, Petiole, Micro-morphology, Conservation. 


\section{Introduction}

Pterygota Schott \& Endl. (Sterculioideae) is a small genus of about 15-20 species comprising trees (Pan \& Jacobs 2007, Oyen, 2008) and has a pan-tropical distribution. Of this number, about 10 occur in tropical Africa and the Indian Ocean Islands (Oyen 2008), while only two (Pterygota bequaertii De Wild and Pterygota macrocarpa K. Schum) are indigenous to West Africa and also occur in Nigeria (Hutchinson \& Dalziel 1958, Keay 1989). The former extends from Ivory Coast to Zaire and occurs in moister areas of the lowland rain forest while the later, Sierra Leone to Zaire and occupies the drier parts of the lowland rain forest. These forest trees are best recognized by the large fruits which contain winged seeds. Leaves are large and heart-shaped, usually 5-7nerved at base. Flowering occurs in February, August and November in P. bequaertii and between November and January in P. macrocarpa while fruiting takes place in February, July to August, November in the former and October to March, June in the later respectively (Hutchinson \& Dalziel 1958, Keay 1989). Timbers of Pterygota species are commercially exploited. P. bequaertii appears to be rather rare over most of its range (Hawthorne 1998), while P. macrocarpa is common, though gradually disappearing. However, Oyen (2008) noted that these two species had been included as vulnerable in the IUCN Red list because of habitat loss and overexploitation. The wood of $P$. macrocarpa is easily impregnated with preservatives, yet, it is not durable, being susceptible to attack by borers, termites and fungi.

In DR Congo, the powdered root of $P$. bequaertii is applied as poultice against chest pain and intercostal pain, while the sticky fruit is used as adhesive paste (Oyen 2008). In Nigeria, a decoction of the leaves of $P$. macrocarpa is drunk against stomach, bladder and urinary prolems and against flatulence (Oyen 2008). Leaf decoctions are also used for the treatment of gonorrhea (GHP 2003, Irvine 1961), while the bark is traditionally used in the management of hemorrhoids, dropsy, swellings, edema, gout, leprosy, and pain (Burkill 1995).

Studies on leaf epidermis have contributed greatly to the taxonomic researches of a number of taxa (Pan \& Jacobs 2007). Various characters have also been used in describing and delimiting species in the present day Sterculioideae, but not much attention has been drawn to the leaf epidermal characters of members of the sub-family and consequently, it is imperative to attempt a search for epidermal characters that may be of taxonomic importance as opined by Aworinde et al. (2012). More so, little is known about the taxonomy and current distribution of Pterygota species, despite their usefulness. This study therefore takes into account the foliar and petiole microcharacters of the genus, with the aim of providing useful diagnostic characters to complement existing taxonomic information of the genus primarily for the identification of the Nigerian and West African species. It also considers the distribution of the species in Nigeria.

\section{Material and methods}

Herbarium specimens of the two species deposited at Forest Herbarium Ibadan (FHI) (Holmgren et al. 1990) as well as fresh specimens of P. macrocarpa collected from the University of Ibadan Botanical Garden and Forestry Research Institute of Nigeria, Ibadan were used for the present study.

\section{Species distributional studies}

Information from existing herbarium collections and filed visits were adequately documented and such were used to produce a distributional map of the studied species, at the GIS unit of Forestry Research Institute of Nigeria, Ibadan using ARCGIS 10.0 .

\section{Foliar micro-morphology}

Dried specimens of $P$. bequaertii were revived in boiling water and cut into small portions, while fresh specimen of $P$. macrocarpa was used without re-hydration. These portions (about 2-5 $\mathrm{cm}^{2}$ ) of the leaves of each species were soaked in concentrated trioxonitrate (v) acid $\left(\mathrm{HNO}_{3}\right)$ in well covered glass Petri dishes for about two hours to macerate the mesophyll. Tissue disintegration was indicated by bubbles and the epidermises were transferred into clean Petri dishes and adequately rinsed with distilled water, before the abaxial and adaxial layers were separated with forceps. Tissue debris was carefully cleared off the epidermises with fine Carmel hair brush, and the isolated epidermal layers were adequately rinsed in water. The epidermises were transferred into another Petri dish containing $50 \%$ ethanol for 1-2 minutes, thereby allowing hardening of cells. Af- 
terwards, tissues were stained with Safranin O for five minutes and then rinsed again in distilled water to remove excess stains. They were thereafter mounted in $15 \%$ glycerol on clear-glass microscopic slides, covered with cover-slips and the edges of the cover slip were ringed with nail varnish to prevent dehydration and thus the slips were sealed to the slides. Five slides were prepared for each epidermis of the two species. Methods followed those of Radford et al. (1974), Metcalf \& Chalk (1979), Khatijah \& Zaharina (1998), Adedeji (2004), Chukwuma et al. (2014) for leaf epidermal descriptions and Carpenter (2005) for stomata architecture.

\section{Petiole micro-morphology}

The petioles (tranverse section) of the two species were cut at $10 \mu$ using a sledge microtome, and preserved in $50 \%$ ethanol. They were stained in aqueous solution of Safranin $\mathrm{O}$ for about $5 \mathrm{~min}$ and rinsed in two changes of distilled water to remove excess stain. There were thereafter mounted in $15 \%$ glycerol, unto glass-microscopic slides, covered with cover slips.

All slides were labelled appropriately and examined under Olympus light microscope with $\times 40$ objective. Photomicrographic images of each specimen were taken with a 14 megapixels Sony digital camera mounted on Olympus photomicroscope at the Department of Forest Products Development and Utilization, Forestry Research Institute of Nigeria (FRIN), Ibadan, Nigeria. Microscope observations and measurements were made with a micrometer eyepiece. For each micromorphological character, measurements were randomly taken from all slides prepared for each specimen. The mean value and standard error for all microscopic parameters were also calculated on the basis of occurrence of each examined character in a total of 20 fields of view, as mentioned above.

\section{Results and discussion}

Distributional studies conducted showed that the species are predominantly distributed in the forest areas of Southern Nigeria with only a few exceptions where $P$. macrocarpa may be found in savannah (Fig. 1). While P. macrocarpa seem to be more abundant throughout the region especially in the South-West, $P$. berqueartii looks more abundant in the South-South area of the country. This distribution pattern suggests that the species may co-exist (sympatric) in the forests of West Africa. Nonetheless, it is imperative to consider the need for active conservation practices and polices within these areas if the World's species are to be saved from total disappearance, especially as the number of endangered species is not accurately known on one hand, the current conservation status of numerous species is also unknown as in the case of those examined in this work while many others are yet to be assessed by the IUCN.

Findings from the foliar micro-morphological studies revealed hypostomatic characteristics in both species. Mean stomata number per view on the abaxial surface ranged from 59 in P. macrocarpa to 115 in P. berqueartii while mean stomatal length and width also ranged from $16.0 \mu \mathrm{m}$ and $8.64 \mu \mathrm{m}$ in the former to $19.20 \mu \mathrm{m}$ and $12.16 \mu \mathrm{m}$ in the latter respectively. Hence, stomata in P. berquaertii are larger than those of P. macrocarpa. In general, they are paracytic in $P$. berquaertii and a combination of paracytic and anomocytic in P. macrocarpa, and numerous on the abaxial surfaces of both species (Tables 1,2).

\begin{tabular}{l|cc|cc|}
\cline { 2 - 5 } & \multicolumn{2}{c}{ P. berquaertii } & \multicolumn{2}{c}{$\boldsymbol{P}$. macrocarpa } \\
\cline { 2 - 5 } Cell type & Abaxial & Adaxial & Abaxial & Adaxial \\
\cline { 2 - 5 } & Polygonal & $\begin{array}{c}\text { Polygonal, } \\
\text { rectangular }\end{array}$ & $\begin{array}{c}\text { Irregular, } \\
\text { polygonal }\end{array}$ & $\begin{array}{c}\text { Irregular, } \\
\text { polygonal }\end{array}$ \\
\hline Crystal & Absent & Absent & Present & Present \\
\hline $\begin{array}{l}\text { Anticlinal } \\
\text { cell wall }\end{array}$ & Straight & $\begin{array}{c}\text { Straight - } \\
\text { curve }\end{array}$ & $\begin{array}{c}\text { Straight, } \\
\text { wavy }\end{array}$ & $\begin{array}{c}\text { Straight - } \\
\text { curve }\end{array}$ \\
\hline $\begin{array}{l}\text { Stomata } \\
\text { type }\end{array}$ & Paracytic & Absent & $\begin{array}{c}\text { Anomocytic, } \\
\text { paracytic }\end{array}$ & Absent \\
\hline Trichome & $\begin{array}{c}\text { Glandular } \\
\text { multicellular }\end{array}$ & Absent & Absent & Absent \\
\hline
\end{tabular}

Tabla 1. Características foliares cualitativas de las especies estudiadas de Pterigota.

Table 1. Qualitative foliar epidermal characteristics of Pterygota species studied.

Epidermal cells are predominantly polygonal with straight anticlinal walls on all the epidermal surfaces, except on the adaxial surface of $P$. bequaertii where it is a combination of polygonal and rectangular cells with oblique ends (Figs. 2, 3 ). While the cell walls are thin on the abaxial surface of $P$. bequaertii, they are thick on other surfaces. Furthermore, trichome was only present on the abaxial surfaces and completely absent on adaxial surfaces of both species. These trichomes can be described as simple, multicellular and glandular types (Fig. 4); ranging from 1-4 in $P$. bequaertii and 1-3 in P. macrocarpa. Interestingly, 


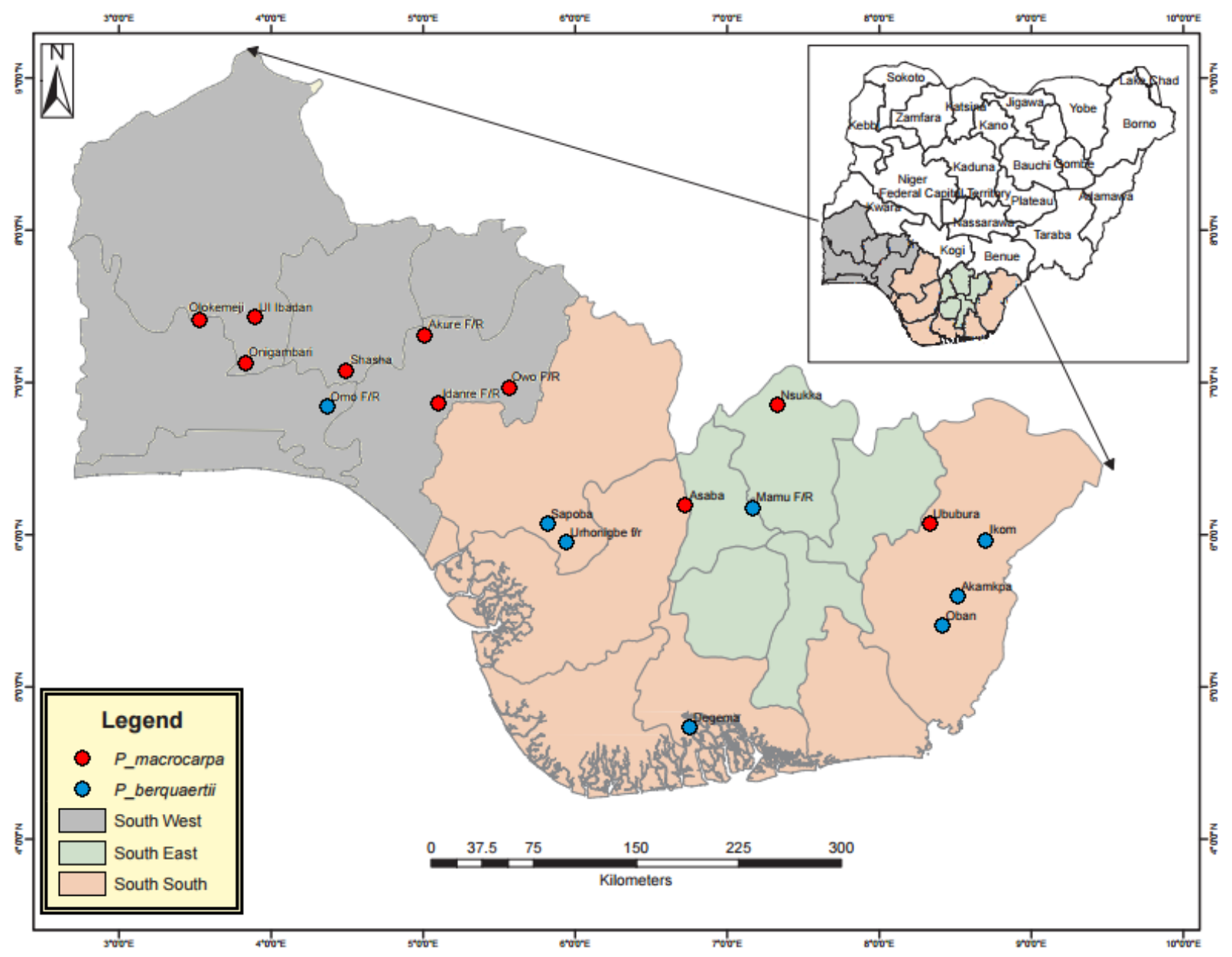

Figura 1. Mapa del sur de Nigeria mostrando la distribución de las especies de Pterigota.

Figure 1. Map of Southern Nigeria showing distribution of Pterygota species

\section{P. berquaertii}

\section{P. macrocarpa}

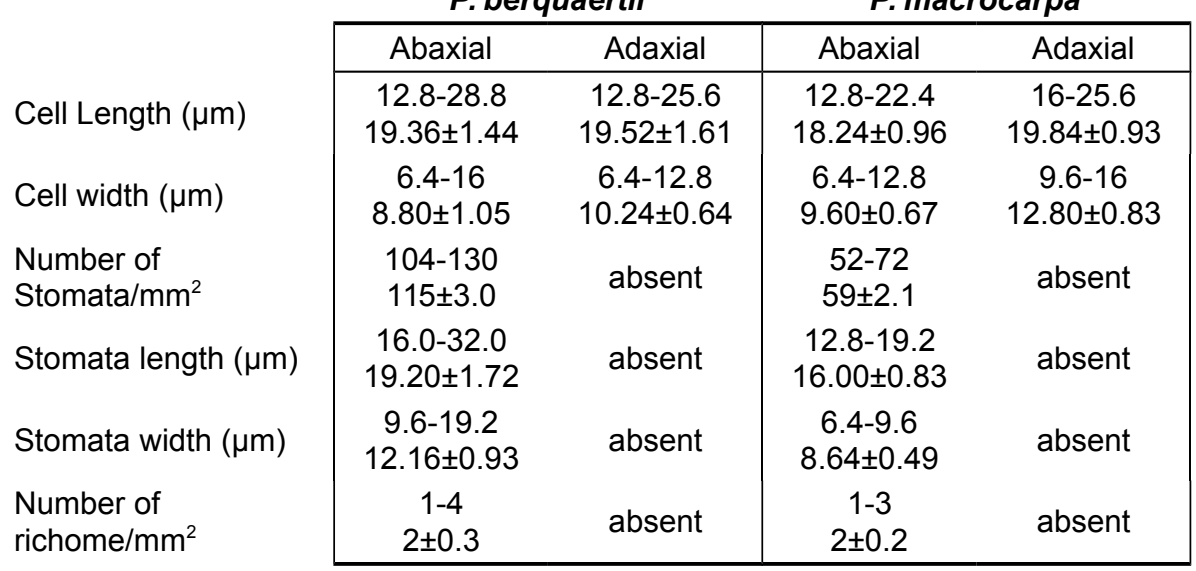

Readings presented as: minimum-maximum (range) above, mean \pm standard error beneath

Tabla 2. Características foliares cuantitativas de las especies estudiadas de Pterigota.

Table 2. Quantitative foliar epidermal characteristics of Pterygota species studied. 


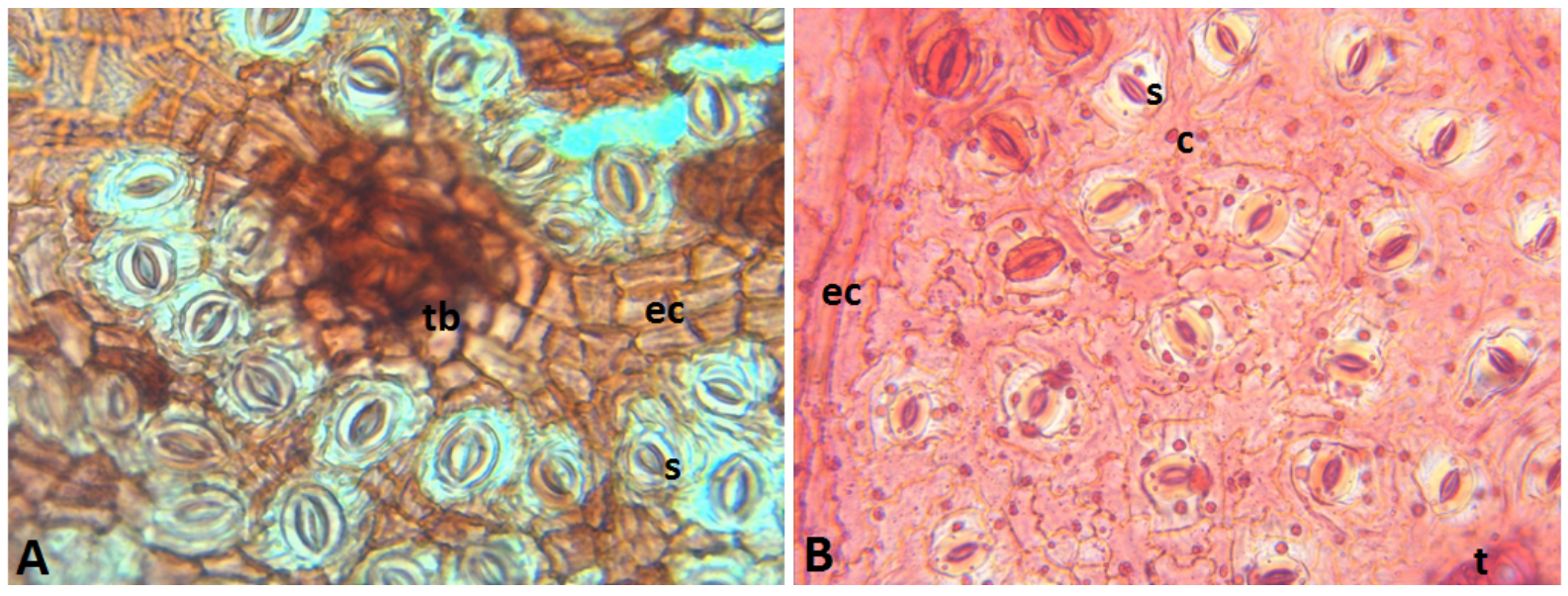

Figura 2. Superficie abaxial de las especies estudiadas de Pterigota x400. A: P. bequaertii; B: P. macrocarpa. c: cristales; ec: células epidémicas; s: estoma; t: tricoma; tb: base del tricoma.

Figure 2. Abaxial surface of Pterygota species studied x400. A: P. bequaertii; B: P. macrocarpa. c: crystals; ec: epidermal cells; s: stoma; t: trichome; tb: trichome base.

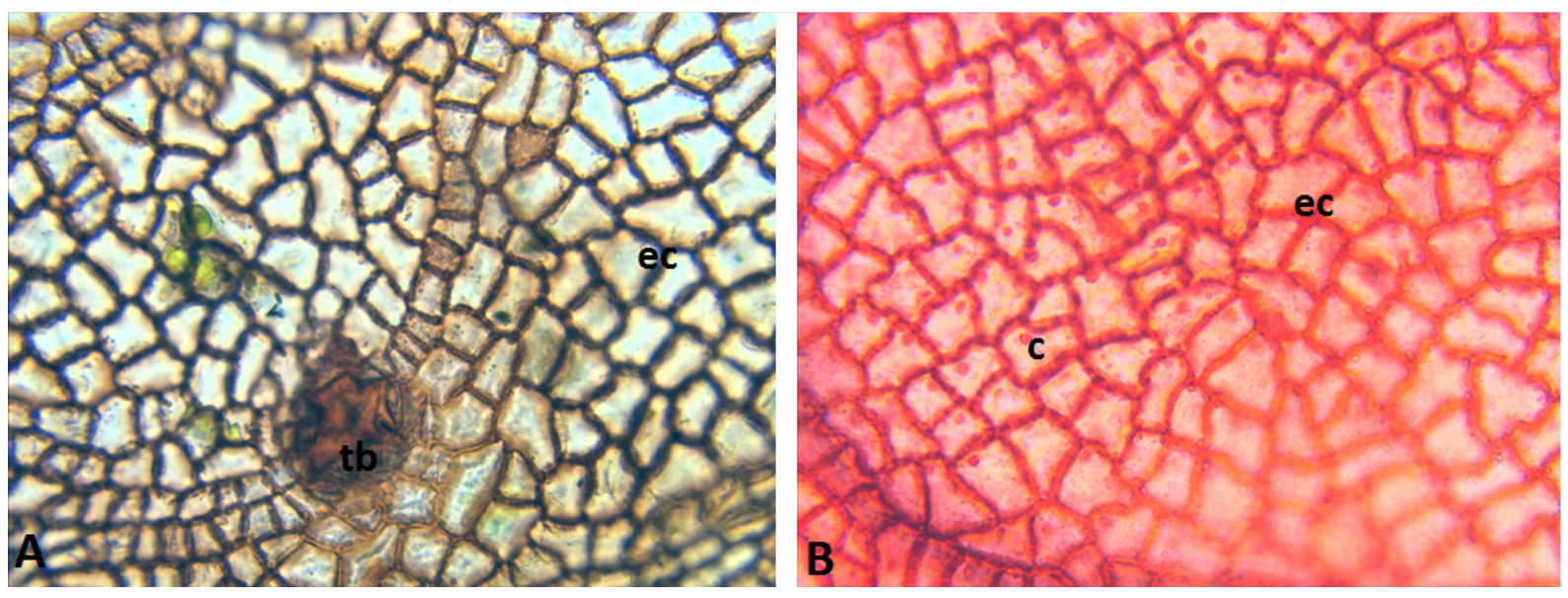

Figura 3. Superficie adaxial de las especies estudiadas de Pterigota x400. A: P. bequaertii; B: P. macrocarpa. ec: células epidémicas; s: stoma; t: tricoma; tb: base del tricoma.

Figure 3. Adaxial surface of Pterygota species studied x400. A: P. bequaertii; B: P. macrocarpa. ec: epidermal cells; s: stoma; t: trichome; tb: trichome base.

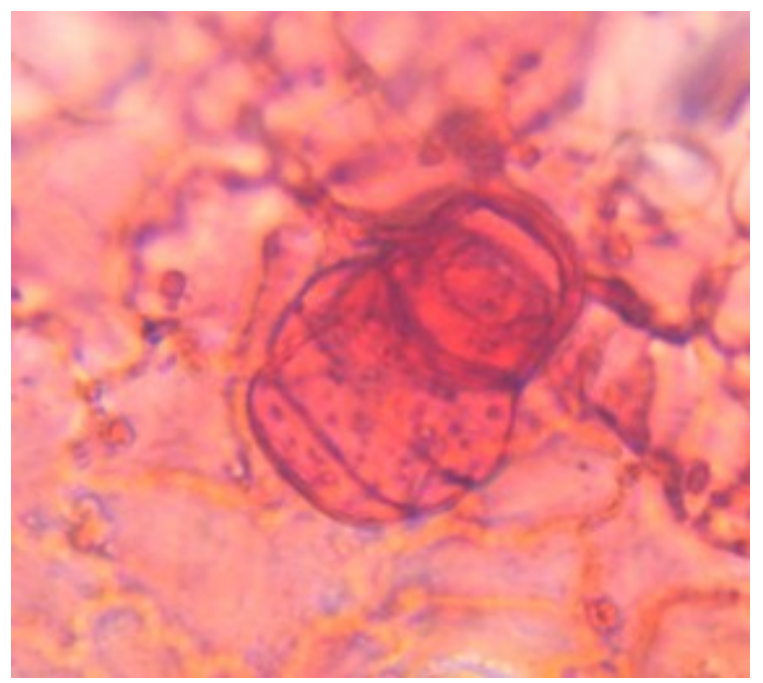

Figura 4. Tricoma simple (glandular) como se observan en las superficies abaxiales de las especies estudiadas de Pterigota $\mathrm{x} 400$. Figure 4. Simple (glandular) trichome as seen on the abaxial surfaces of Pterygota species studied $\mathrm{x} 400$. 

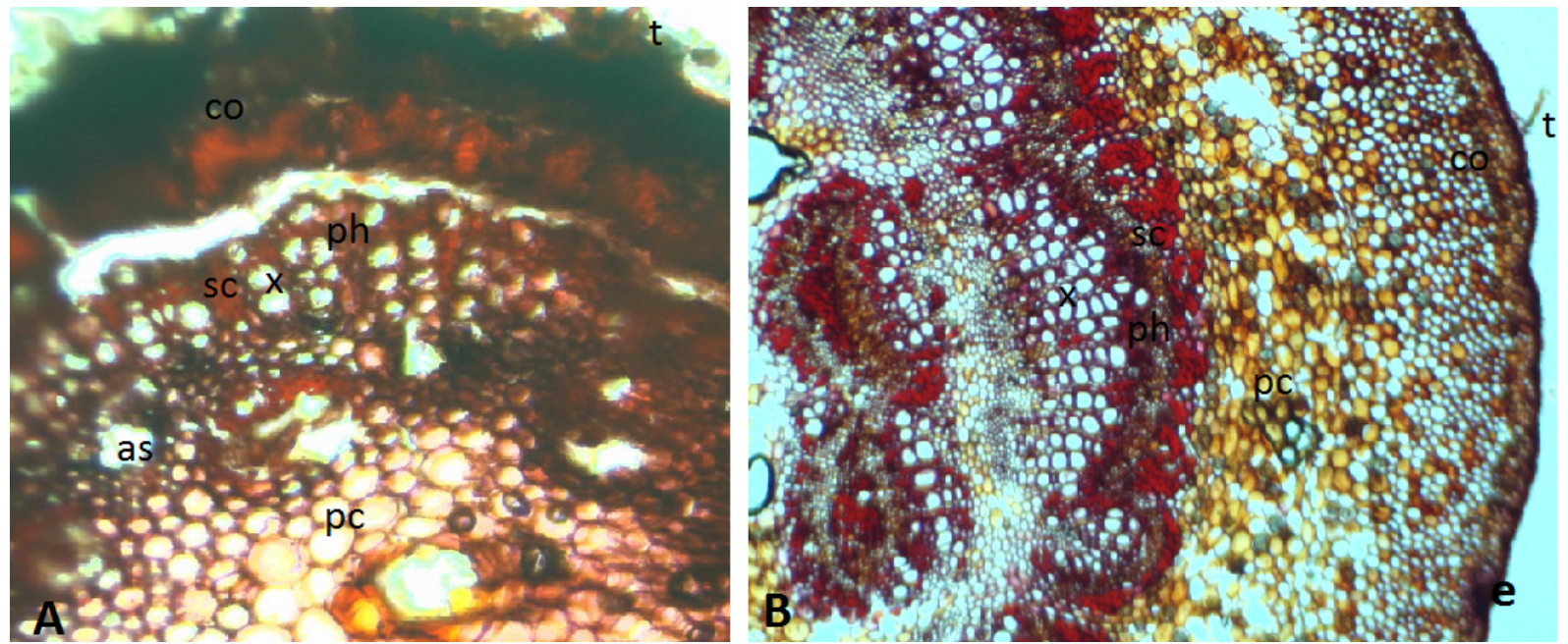

Figura 5. Sección transversal del peciolo de las especies estudiadas de Pterigota x100. A: P. bequaertii; B: P. macrocarpa. as: espacio aéreo; co: colénquimas; e: epidermis; pc: parénquima; ph: floema; sc: esclerénquima; t: tricoma; $x$ : xilema.

Figure 5. Transverse section of the petioles of Pterygota species studied x100. A: P. bequaertii; B: P. macrocarpa. as: air space; co: collenchymas; e: epidermis; pc: parenchyma; ph: phloem; sc: sclerenchyma; t: trichome; $x$ : xylem.

the adaxial surface of $P$. bequaertii consist of numerous trichome base but trichome was totally absent, hence suggesting an advanced characteristics of this species.

A cross-section of the petiole also revealed solitary cell distribution in P. bequaertii and a combination of solitary and radial multiple cells in $P$. macrocarpa (Fig 5). Petiole outline is generally spherical in the two species, with uniseriate epidermis. Cortex consists predominantly of polygonal angular collenchyma cells and thin walled parenchyma cells. Collenchyma is 2-3 layered in $P$. berquaertii and multi-layered in P. macrocarpa. Vascular bundles are larger in P. macrocarpa than in the petiole of $P$. bequaertii while trichomes are simple unicellular in the former and stellate in the latter. Furthermore, layers of thin-walled parenchymatous cells also are present in the pith of the petiole, in the two species studied. The presence of large air spaces in the petiole of $P$. bequaertii could also be a useful characteristic for the delimitation of the taxa studied in sterile conditions.

However, it is noteworthy that, the role of anatomical data in traditional taxonomy has long been recognized by many researchers (Metcalfe \& Chalk 1979, Soladoye 1982), since the variations within the species, genera or a family is also usually reflected in anatomical features. Moreso, leaf epidermal features such as stomata types, epidermal cells, presence or absence of crystals, trichomes amongst others, are thus useful anatomical tools (Jayeola et al. 2001, Adedeji \& Iloh 2004, Aworinde et al. 2012, Akinnubi et al. 2013,
Chukwuma et al. 2014); and have provided valuable supplementary evidence of potential taxonomic value (Watson 1962, Baronova 1992). Wilkinson (1979) noted that, the taxonomic significance of the similarity of stomata apparatus in a mature leaf often provides a reliable diagnostic character, particularly when the ontogeny of the stomata is unknown or different. Radford et al. (1974) also noted that anatomical data tend to be most useful at the generic level and higher taxonomic categories, and they have proven most reliable in statements of negation of close relationship rather than positive assertions of relationship. However, it is important to note that a natural classification can be attained only when anatomical information is combined with other taxonomic evidences such as morphological, cytological, palynological etc.

\section{Conclusion}

This study has shown the relevance of foliar and petiole micro-characters in the study of Pterygota species in Nigeria and West Africa at large. It has also revealed the distribution of the species in $\mathrm{Ni}$ geria, from herbarium records and field observations. Although, the foliar epidermises and transverse sections of the petioles show overlapping characteristics as observed, the quantitative characteristics of the stomata, and the presence or absence of crystals on the foliar epidermises on one hand, and trichome types and cell distribution in the petioles on the other hand, can be useful in 
distinguishing $P$. berquaertii from $P$. macrocarpa. While this study agrees with the existing taxonomic reports on the species, it advocates the need for a complete systematic study of the genus and the entire Sterculioideae to better understand the timing of independent evolution of the species, and to further ascertain the current placement of the sub-family (Sterculioideae) in the Plant Kingdom.

\section{References}

Adedeji O. 2004. Leaf Epidermal Studies of Emilia Cass. (Senecioneae, Asteraceae) in Nigeria. Botanica Lithuania, 10 (2): 12-133.

Adedeji O \& Iloh HC. 2004. Comparative foliar anatomy of ten species in the genus Hibiscus Linn, in Nigeria. New Botanist, 31: 147-180.

Akinnubi FM, Akinloye AJ \& Oladipo OT. 2013. Petiole anatomy of some species of Asteraceae in southwest Nigeria. African Journal of Plant Science 7(12) 608-612.

Aworinde DO, Ogundairo BO, Osuntoyinbo KF \& Olanloye OA. 2012. Foliar Epidermal characters of some Sterculiaceae species In Nigeria. Bayero Journal of Pure and Applied Sciences 5(1): 48-56.

Baronova M. 1992. Principles of comparative stomatographic studies of flowering plants. The Botanical review, 58: 1-9.

Burkill HM. 1995. The Useful Plants of West Tropical Africa, vol. 3, Royal Kew Botanical Gardens, London, UK, 2nd edition.

Carpenter KJ. 2005. Stomatal Architecture and evolution in Basal Angiosperm. American Journal of Botany 92 (10): 1595-1615.

Chukwuma EC, Soladoye MO \& Abdus Salaam KRP. 2014. Taxonomic value of the leaf micro-morphology and quantitative phytochemistry of Clitoria ternatea and Centrosema pubescens (Papilionoideae, Fabaceae). Phytologia Balcanica 20(1): 3-8.

Ghana Herbal Pharmacopoiea (GHP) 2003. The Advent Press, Accra, Ghana, 2003.

Hawthorne W. 1998. Pterygota bequaertii. The IUCN Red List of Threatened Species 1998
E.T33059A9746246. 5pp.

Holmgren PK, Keuken W \& Schofield EK. 1990. Index Herbariorum Part I. The Habaria of the World. 8th ed. Reg. Veg., 120 - New York.

Hutchinson J \& Dalziel JM. 1958. Flora of West Tropical Africa (Vol. 1 Pt. 2). Crown Agents for Oversea Governments and Administrations, Millbank, London, pp 335-350.

Irvine FR. 1961. Woody Plants of Ghana, Oxford University Press, London, UK.

Jayeola, A.A., Thorpe, J.R. \& Adenegan, J.A. 2001. Macromorphological and micromorphological studies of the West African Rhizophora L. Feddes Repertorium 112: 349-356.

Keay RWJ. 1989. Trees of Nigeria. Oxford University Press, New York. 476pp.

Khatijah HN \& Zaharina MS. 1998. Comparative Leaf anatomical studies of some Sterculia L. species (Sterculiaceae). Botanical Journal of the Linnean Society 127: 159-174.

Metcalfe CR \& Chalk L. 1979. Anatomy of the Dicotyledons. 2nd ed, Vol. 1. Clarendon Press, Oxford. 275pp.

Oyen LPA. 2008. Pterygota macrocarpa K. Schum. In: Loupe D, Oteng-Amoako AA \& Brink M (eds.). Plant Resources of Tropical Africa 7(1). Timbers. PROTA Foundation, Wageningen, Netherlands / Backhuys Publishers, Leiden, Netherlands. pp 493-497.

Pan AD \& Jacobs BF. 2007. The earliest record of the genus Cola (Malvaceae sensu lato: Sterculioideae) from the Late Oligocene (28-27 Ma) of Ethiopia and leaf characteristics within the genus. Plant Systematics and Evolution 283(3/4): 247-262.

Radford AE, Dickson WC, Massey JR \& Bell CR. (eds.) 1974. Vascular Plant Systematics. Harper and Row Publishers, New York. 886pp.

Soladoye MO. 1982. Leaf Epidermal Studies in the African Genus Baphia Lodd. and related genera (Papilionoideae-Sophoreae). Bulletin du Jardin Botanique National de Belgique 52: 415-437.

Watson L. 1962. The taxonomic significance of stomata distribution and morphology in Epacridaceae. New Phytologist 61: 36-40.

Wilkinson HP. 1979. The Plant surface (Mainly leaf) In. Metcalfe, C.R. and chalk, L. (Eds). Anatomy of the Dicotyledons Vol. 1 (2nd ed). Oxford Clarendon press, pp 40-53. 